\title{
Experimental shift of diet and DIC stable carbon isotopes: Influence on shell $\delta 13 C$ values in the Manila clam Ruditapes philippinarum
}

\author{
C. Poulain ${ }^{a}{ }^{\text {* }}$, A. Lorrain ${ }^{a}$, R. Mas ${ }^{b}$, D.P. Gillikin ${ }^{c}$, F. Dehairs ${ }^{b}$, R. Robert ${ }^{d}$ and Y.-M. Paulet ${ }^{a}$
}

\author{
a LEMAR, UMR CNRS/UBO/IRD 6539, Institut Universitaire Européen de la Mer, Place Nicolas Copernic, 29280 \\ Plouzané, France \\ ${ }^{\mathrm{b}}$ Earth System Sciences Research Group and Dept. of Analytical and Environmental Chemistry, Vrije Universiteit \\ Brussel, Pleinlaan 2, 1050 Brussels, Belgium \\ c Department of Earth Science and Geography, Vassar College, Poughkeepsie, New York 12604, USA \\ d IFREMER, UMR « Laboratoire de Physiologie des Invertébrés », Station Expérimentale d'Argenton, Presqu'ile \\ du vivier, 29840 Argenton, France
}

*: Corresponding author : C. Poulain, Tel.:+ 332984988 38; fax: + 332984986 45, email address :
celine.poulain@univ-brest.fr

\begin{abstract}
:
The influences of diet and seawater dissolved inorganic carbon (DIC) on the carbon isotope composition of shell aragonite $\left(\delta^{13} \mathrm{C}_{\text {shell }}\right)$ in the Manila clam Ruditapes philippinarum reared under laboratory conditions were investigated. Clams were exposed to two successive negative carbon isotope shifts: a first shift in diet $\left(\delta^{13} C_{\text {phytoplankton }}\right)$ and a second shift, 35 days later, in DIC $\left(\delta^{13} C_{D I C}\right)$. Both successive shifts induced a decrease in $\delta^{13} C_{\text {shell. }}$. These results are the first to experimentally confirm an incorporation of respired carbon derived from food and carbon from DIC into shell carbonate of adult bivalves. Skeletal $\delta^{13} \mathrm{C}$ responded to changes in the $\delta^{13} \mathrm{C}$ of both diet and DIC in less than 7 days. Consequently, proxies based on $\delta^{13} \mathrm{C}_{\text {shell }}$ may be used with high temporal resolution. Using $\delta^{13} C_{\text {phytoplankton }}$ as a proxy for the carbon isotope composition of respired carbon $\left(\delta^{13} C_{R}\right)$ resulted in a rather constant percentage of metabolic carbon $\left(\mathrm{C}_{\mathrm{M}}\right)$ into the shell carbonate over time (close to $12 \%)$. However, an accurate estimation of $\delta^{13} C_{R}$ is required in order to precisely estimate the percentage of metabolic carbon incorporated into the shell. Despite the significant incorporation of metabolic carbon into shell carbonate, our experimental results revealed that $\delta^{13} C_{\text {shell }}$ was highly correlated with $\delta^{13} \mathrm{C}_{\text {DIC }}\left(r^{2}=0.77, p<0.0001\right)$. Thus it seems that $\delta^{13} \mathrm{C}_{\text {shell }}$ is a promising proxy of large scale variations in $\delta^{13} \mathrm{C}_{\mathrm{DIC}}$ and therefore of salinity in estuarine water.
\end{abstract}

Keywords: $\delta^{13} \mathrm{C}_{\text {shell }}$; DIC; Salinity; Metabolic carbon; Ruditapes philippinarum; Estuarine water; Proxy 


\section{Introduction}

Bivalves record environmental information in the form of chemical or structural messages archived in their calcareous exoskeleton during growth. For this reason, they are widely used for paleo-climatic and paleo-oceanographic reconstructions (e.g. Davenport, 1938, Weidman et al., 1994 , Tripati et al., 2001, Dutton et al., 2002 , Schöne et al., 2003, Lazareth et al., 2006, Ivany et al., 2008, Goewert and Surge, 2008, Wanamaker et al., 2008). Epstein et al. (1953) showed that oxygen isotope composition of mollusk shells $\left(\delta^{18} \mathrm{O}_{\text {shell }}\right)$ reflect the temperature and oxygen isotope composition of the water $\left(\delta^{18} \mathrm{O}_{w}\right)$ in which they were formed. This allows the use of shell carbonate $\delta^{18} \mathrm{O}$ as a temperature proxy at least in cases where $\delta^{18} \mathrm{O}_{\mathrm{w}}$ remains constant and is known (e.g. Weidman et al., 1994, Chauvaud et al., 2005, Andrus and Rich, 2008). However, $\delta^{18} \mathrm{O}_{\mathrm{w}}$ is often strongly dependant on salinity (Epstein and Mayeda, 1953, Craig and Gordon, 1965, Mook and Tan, 1991, Dettman et al., 2004). Therefore, the estimation of $\delta^{18} \mathrm{O}_{\mathrm{w}}$ is difficult without an independent salinity proxy in environments displaying large salinity variations such as estuaries. In well flushed estuaries with short residence times, stable carbon isotope composition of dissolved inorganic carbon $\left(\delta^{13} \mathrm{C}_{\mathrm{DIC}}\right)$ is well correlated with salinity year round, especially when salinity is higher than 25 (Mook, 1971, Surge et al., 2001, Fry, 2002, Gillikin et al., 2006). As carbon precipitating during shell mineralization is known to originate mainly from dissolved inorganic carbon (DIC) of seawater (Mook and Vogel, 1968, McConnaughey et al., 1997 , Gillikin et al., 2006, McConnaughey and Gillikin, 2008, Owen et al., 2008), the carbon isotope composition of bivalve shells $\left(\delta^{13} \mathrm{C}_{\text {shell }}\right)$ living in estuaries may possibly be used for reconstructing past variations of salinity. A paleo-salinity proxy would also be useful for correcting paleotemperature based on $\delta^{18} \mathrm{O}$ of estuarine bivalve shells (see Gillikin et al., 2006).

The carbon isotope composition of bivalve shell carbonates is, however, not only affected by $\delta^{13} \mathrm{C}_{\mathrm{DIC}}$, but also by the physiology of the bivalve (Dillaman and Ford, 1982, Tanaka et al., 1986, McConnaughey et al., 1997, Lorrain et al., 2004, Gillikin et al., 2006, 2007, 2009, McConnaughey and Gillikin, 2008). Previous studies have shown that isotopically light metabolic carbon, derived from food, is incorporated into shell carbonate (e.g. Tanaka et al., 1986, McConnaughey et al., 1997, Wanamaker et al., 2007, Owen et al., 2008, Gillikin et al., 2006, 2007, 2009). However, the processes of metabolic carbon incorporation into the shell remain poorly known and the estimation of metabolic carbon contribution to the shell appears highly variable between studies. McConnaughey et al. (1997), Lorrain et al. (2004) and 
Gillikin et al. (2006) estimated the percentage of metabolic carbon integrated into the shell to be lower than $10 \%$ in deep-sea mollusks, Pecten maximus and Mytilus edulis, whereas Gillikin et al. (2007, 2009) found values between 25 and $40 \%$ in marine Mercenaria mercenaria and freshwater Unionid shells, respectively. Consequently, development of environmental proxies based on $\delta^{13} \mathrm{C}_{\text {shell }}$ requires a better understanding of the processes involved in the incorporation of metabolic carbon into the bivalve shell.

In the present study we performed a laboratory experiment using the Manila clam, Ruditapes philippinarum (Adams and Reeve, 1850). This bivalve species, which has an aragonitic shell, was chosen for several reasons. First, it is an euryhaline bivalve living mainly at salinity levels ranging from 16 to 36 (Nie, 1991), buried a few centimeters in sandy and muddy sediments in intertidal to subtidal zones. Because of its importance for aquaculture and fisheries this species is well studied regarding its biology and physiology (e.g. Goulletquer et al., 1989, Kim et al., 2001, Richardson, 1987, Marin et al., 2003, Flye-Sainte-Marie et al., 2007). Moreover, clams, and particularly Ruditapes genus, are frequently found in shellmiddens, and are therefore suitable candidates as archives of past coastal human settlements (Dupont and Marchand, 2008).

During this laboratory experiment, clams were reared under controlled values of $\delta^{13} \mathrm{C}_{\text {phytoplankton }}$ which were more depleted than those encountered in the field. Moreover, after 35 days of experiment, three salinity conditions and therefore three $\delta^{13} \mathrm{C}_{\text {DIC }}$ were tested. The aims of this study are (1) to demonstrate the incorporation of the two carbon sources (DIC from surrounding seawater and DIC originating from respiration) into adult bivalve shells, which, to our knowledge, has never been demonstrated experimentally, (2) to study the response time of these carbon incorporations into the shell, and (3) to investigate the potential use of $\delta^{13} \mathrm{C}_{\text {shell }}$ as a proxy of high $\delta^{13} \mathrm{C}_{\text {DIC }}$ variations and therefore of salinity in estuarine water. In parallel, this experiment was designed to assess the effect of salinity variations on clam physiology (i.e. condition index, shell growth rate and incorporation of carbon into soft tissues) which has potential impacts on shell mineralization processes.

\section{Material and methods}

\subsection{Biological material}

A total of 250 Manila clams (R. philippinarum; two to three-years old; average length $27 \mathrm{~mm}$; $1 \sigma=2 \mathrm{~mm}$ ) were collected by hand at low tide in an estuary located in the Gulf of Morbihan 
115 (Bay of Kerdréan, $47^{\circ} 37^{\prime}$ N, $2^{\circ} 56^{\prime} \mathrm{W}$; Brittany; France; semidiurnal tidal regime) on the $18^{\text {th }}$ 116 of August 2008. Clams were transferred to French Research Institute for Exploitation of the 117 Sea (IFREMER) Argenton Shellfish Laboratory (North Finistère, France).

\subsection{Experimental conditions}

120 Clams were randomly divided into three batches of 80 individuals and each batch was placed

121 into a $25 \mathrm{~L}$ tank without sediment. Water within the tanks was homogenized with an aquarium

122 pump. Each tank was supplied with UV sterilized water from a $300 \mathrm{~L}$ buffer tank allowing 123 renewal rate of $25 \% \mathrm{~h}^{-1}$ and complete water changes were made once a week. The $300 \mathrm{~L}$ 124 buffer tanks were filled every 2 to 3 days with $1 \mu \mathrm{m}$ filtered, UV sterilized water at room 125 temperature. The experimental system is illustrated in Fig. 1.

126 Water flowing into the $25 \mathrm{~L}$ tanks was supplemented continuously during the entire 127 experiment with cultured microalgae (50\% Isochrysis affinis galbana (Tahitian strain T.iso) 128 and 50\% Chaetoceros calcitrans $)$ depleted in ${ }^{13} \mathrm{C}\left(\delta^{13} \mathrm{C}=-58 \%\right.$; $1 \sigma=4 \%$ $\sigma .{ }^{13} \mathrm{C}$ depleted 129 microalgae were obtained by bubbling ${ }^{13} \mathrm{C}$-depleted industrial $\mathrm{CO}_{2}$ into the culture medium 130 (see Paulet et al., 2006 for elaboration). Algae were cultured at a salinity of 35. The 131 experiment was performed over 64 days, during which temperature $\left(20^{\circ} \mathrm{C}\right)$ and photoperiod (12/12) were kept constant.

134 During the first 35 days, salinity of the three tanks was maintained constant at 35 . From days 13535 to 64 , one tank was kept at 35 , while salinity was modified to 28 and 20 in the other two 136 tanks. Salinities of 20 and 28 were obtained by mixing seawater and tap water within the 300

137 L buffer tanks, and salinity was checked and adjusted using a conductivity meter (WTW, LF 138 197-S). Salinity was recorded every five minutes in the three tanks using an autonomous data logger (YSI-600 OMS) from day $7\left(\mathrm{t}_{7}\right)$ to the end of the experiment $\left(\mathrm{t}_{64}\right)$.

\subsection{Sampling}

\subsubsection{Biological sampling}

\section{Soft tissue sampling}

144 During the first 35 days, while salinity was similar in all three tanks, two clams per tank were 145 collected each week. After the salinity change, five clams were randomly collected from each 146 tank weekly. Adductor and posterior muscle, digestive gland (without purging the digestive 
tract) and mantle (without siphon) were dissected from each individual and were frozen at $20^{\circ} \mathrm{C}$. In order to determine initial isotope composition of tissues at the beginning of the experiment $\left(\mathrm{t}_{0}\right)$, five clams from the field were processed in the same way. In addition, five clams per tank were collected at $\mathrm{t}_{35}$ and $\mathrm{t}_{64}$, and total soft tissues from each individual were frozen at $-20^{\circ} \mathrm{C}$. At the end of the experiment, tissues were freeze-dried (48h) and shells were air-dried. Tissues and shell were weighed in order to estimate the condition index (CI), following Lucas and Beninger, (1985) :

$\mathrm{CI}=($ Soft Tissues Dry Weight $/$ Shell Dry Weight $) \times 100$.

\section{Calcein marking and shell sampling}

Two calcein markings were used to establish a temporal scale in the shells. Clams in each salinity treatment were exposed to a $150 \mathrm{mg} \mathrm{L}^{-1}$ calcein solution during 4 hours (Rowley and Mackinnon, 1995, Thébault et al., 2005) at days $15\left(\mathrm{t}_{15}\right)$ and $35\left(\mathrm{t}_{35}\right)$. At the end of the experiment $\left(\mathrm{t}_{64}\right), 30$ clams from each salinity were sacrificed and their shells were used for growth rate determination and calcium carbonate sampling.

\subsubsection{Food and DIC sampling}

In order to determine the carbon isotope composition of the diet during the experiment, $15 \mathrm{~mL}$ of the algal mix was filtered on a precombusted Whatman GF/F filter every week. Following Lorrain et al. (2003), filters were immediately dried for $12 \mathrm{~h}$ at $60^{\circ} \mathrm{C}$ and stored until analysis. When the clams were collected, water was sampled in the field and $200 \mathrm{~mL}$ was filtered on a precombusted Whatman $\mathrm{GF} / \mathrm{F}$ filter to determine the carbon isotope composition of particulate organic matter $\left(\delta^{13} \mathrm{C}_{\mathrm{POM}}\right)$ using the method described above. The suspended POM pool is a mixture of different sources of carbon (e.g. phytoplankton, microphytobenthos, resuspended sediment, terrestrial carbon, marine micro-algae detritus). However, $\delta^{13} \mathrm{C}_{\mathrm{POM}}$

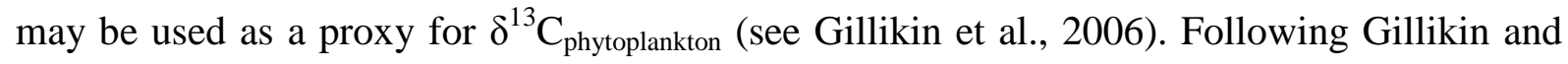
Bouillon (2007), water from the field and water within the $25 \mathrm{~L}$ clam tanks were sampled at $\mathrm{t}_{0}$ and weekly respectively using $12 \mathrm{~mL}$ glass vials and poisoned with $20 \mu \mathrm{L}$ of saturated mercuric chloride $\left(\mathrm{HgCl}_{2}\right)$ solution until analysis of the DIC isotope composition.

\subsection{Shell preparation and calcium carbonate sampling}

For the purposes of calcium carbonate sampling, 30 shells were collected from each tank at day 64 (end of experiment). A $8 \times 10 \mathrm{~mm}$ piece of the shell, including the new shell material 
180 formed during the experiment, was cut from the shell edge along the major growth axis and embedded in epoxy resin (Araldite 2020, DIL, France). A cross-section (800 $\mu \mathrm{m}$ thick) was then cut using a low speed diamond saw and glued on a glass slide with epoxy resin. Thick sections were then ground with wet sandpaper (1200, 2400 and $4000 \mu \mathrm{m}$ grit size) and polished with a suspended diamond solution $(3 \mu \mathrm{m})$. Shell sections were observed under a fluorescence microscope (OLYMPUS BX41) equipped with a $50 \mathrm{~W}$ high-pressure $\mathrm{Hg}$ lamp and a calcein filter. Photographs were acquired using a Hamamatsu C4742-95 digital camera fitted on the microscope. The $R$. philippinarum shell consists of two aragonitic layers, an inner homogeneous layer and an outer prismatic layer. Four evident marks in the outer layer allowed assigning calendar dates on the shell sections: a cleft presumably due to the shell growth stop induced by clam's collection in the field, the two calcein marks and the ventral margin which sets the date the experiment was ended. For the 30 clams per tank collected on the final day, growth between the four growth checks was measured on the shell section photograph using the software Visilog 6.6. Five of the 30 shells (per batch) were selected based on age (two-year old clams were selected to avoid any effect of ontogeny) and on high shell growth rate to obtain sufficient material for carbon isotopic analysis. Since the tidal periodicity of shell growth increment formation at intertidal flats is not lost in $R$. philippinarum even after several months in constant laboratory conditions without emersion (Richardson, 1987), it was possible to assign a calendar date to each growth increment (with a precision of 3 days due to the behavioral disturbance induced by handling). Calcium carbonates samples (average weight $=70 \mu \mathrm{g}$ ) were drilled to a depth of $350 \mu \mathrm{m}$ in the middle of the prismatic layer using a MicroMill (Merchantek) fitted with a $300 \mu \mathrm{m}$ diameter drill bit. One carbonate sample was drilled just before the cleft induced by clam collection in order to measure the field isotopic value $\left(\mathrm{t}_{0}\right)$, one sample was drilled between the cleft and the first calcein mark, two samples were drilled between the first and the second calcein mark and three samples were drilled after the second calcein mark (see Fig. 2). Aragonite powder samples were stored in glass vials until analysis.

\subsection{Isotopic analyses}

209 Freeze-dried tissues were ground to a homogeneous fine powder. $500 \mu \mathrm{g}$ of the powder was 210 packed into $5 \times 9 \mathrm{~mm}$ precombusted silver cups. Carbon stable isotope analysis was performed 211 at the Earth System Sciences laboratory (Vrije Universiteit Brussel) using an Elemental 212 Analyzer (Flash 1112 EA Thermo Finnigan) coupled via a CONFLO III to a Thermo Delta V 
213 Plus isotope ratio mass spectrometer (IRMS). A total of 42 samples of the international 214 isotopic reference standard IAEA-CH-6 (-10.45 $\pm 0.030 \%$ o) were analyzed with the samples 215 and yielded a reproducibility $(1 \sigma)$ of $0.36 \%$ for $\delta^{13} \mathrm{C}$.

216 Filters were decarbonated via a 4-h exposure to $\mathrm{HCl}$ fumes in a dessicator (Lorrain et al., 217 2003) and were packed into $5 \times 9 \mathrm{~mm}$ tin cups. Isotopic analysis was performed as described 218 for the tissues.

219 The $\delta^{13} \mathrm{C}$ of the total DIC was analyzed according to the protocol of Gillikin and Bouillon, 220 (2007). Briefly, $9.5 \mathrm{~mL}$ of water sample were acidified with $200 \mu \mathrm{L}$ of pure orthophosphoric 221 acid in a $12 \mathrm{~mL}$ helium-flushed headspace vial, followed by overnight equilibration and injection of $500 \mu \mathrm{L}$ headspace into the carrier gas stream of the continuous flow EA-IRMS (same instrument used for tissues and diet). The Miyajima et al. (1995) algorithm was used to correct for the partitioning of $\mathrm{CO}_{2}$ between headspace and water phase and to calculate the $\delta^{13} \mathrm{C}_{\text {DIC. }}$. Along with the headspace injections a $\mathrm{CO}_{2}$ house standard was injected $(\mathrm{n}=28,1 \sigma$

$226=0.2 \%$ ). Based on this and an average reproducibility of DIC sample measurements of 0.11 $\%$, a precision of the $\delta^{13} \mathrm{C}_{\text {DIC }}$ better than $0.2 \%$ ( $\left.1 \sigma\right)$ can be expected (also see Gillikin and 228 Bouillon, 2007).

229 All carbonate isotopic analyses were performed on a Finningan MAT 252 IRMS equipped 230 with a Kiel III automated sampling device at the University of Arizona, USA. Samples were 231 reacted with $>100 \%$ orthophosphoric acid at $70^{\circ} \mathrm{C}$. The standard deviation of replicate 232 carbonate standards was $0.08 \%$ o $(1 \sigma)$. All carbon isotopic results are reported relative to 233 VPDB (Vienna Pee Dee Belemnite) by calibration to the NBS-19 reference standard $\left(\delta^{13} \mathrm{C}=\right.$ $234+1.95 \%$ )

\subsection{Data analysis}

237 All statistical analyses were performed using the software Statgraphics. Homoscedasticity was tested using Bartlett's test $(\alpha=0.05)$. ANOVAs were performed to check: (1) the differences in mean shell growth of clams for the three salinity conditions between $t_{35}$ and $t_{64}$, and (2) the differences in carbon isotope composition between the different salinity conditions for each organ at each sampling date. The differences in condition index between the three salinity conditions were tested by performing non-parametric Kruskal-Wallis test. 


\section{Results}

\subsection{Animal growth and condition during the experiment}

All clams exhibited significant growth during the experiment with shell growth between the $1^{\text {st }}$ calcein marking $\left(\mathrm{t}_{15}\right)$ and the shell edge $\left(\mathrm{t}_{64}\right)$ of $1986 \mu \mathrm{m}(1 \sigma=1037 \mu \mathrm{m} ; \mathrm{n}=90$; see Fig. 2). The two bright calcein marks and the cleft induced by clam collection from the field were readily identifiable in all shells. The three salinity treatments tested between day $35\left(^{\text {nd }}\right.$ calcein marking) and the end of the experiment (shell edge) induced no significant differences on shell growth (ANOVA, $p=0.32)$ with a mean shell growth of $1402 \mu \mathrm{m}(1 \sigma=752 \mu \mathrm{m} ; \mathrm{n}=$ 30), $1368 \mu \mathrm{m}(1 \sigma=598 \mu \mathrm{m} ; \mathrm{n}=30)$ and $1135 \mu \mathrm{m}(1 \sigma=663 \mu \mathrm{m} ; \mathrm{n}=30)$ at salinities 35,28 and 20 , respectively.

The condition index was almost constant during the entire experiment (average value $=8.80$; $1 \sigma=1.85$ ). Between days 35 and 64 , at each sampling date, there were no significant differences in average values of condition index between the three salinities conditions (Kruskal-Wallis, $p>0.05$ ).

\subsection{Salinity and $\delta^{13} C_{D I C}$}

During the first 35 days, salinity of the three tanks was $35.42(1 \sigma=0.21), 35.77(1 \sigma=0.11)$ and $35.36(1 \sigma=0.10)$ respectively. From days 35 to 64 , the first tank was maintained at 35.28 $(1 \sigma=0.16)$, while salinity was changed to $28.02(1 \sigma=0.14)$ and $20.76(1 \sigma=0.13)$ in the two other tanks.

The carbon isotopic DIC values in the experimental tanks ranged between $-1.28 \%$ and -3.34 $\% o$ at salinity 35 , between $-4.97 \%$ and $-5.90 \%$ at salinity 28 and between $-8.33 \%$ and -9.52 $\% o$ at salinity 20 (Fig. 3A). There was a high positive correlation between $\delta^{13} \mathrm{C}_{\mathrm{DIC}}$ and salinity $\left(\delta^{13} \mathrm{C}_{\mathrm{DIC}}=0.424 \times\right.$ salinity $\left.-17.04, \mathrm{r}^{2}=0.95, p<0.0001, \mathrm{n}=16\right)$ as shown in Fig. 3B.

\section{$3.3 \delta^{13} C_{\text {tissues }}$}

From days 35 to 64 , there was no significant effect of salinity on $\delta^{13} \mathrm{C}$ values for digestive gland and muscle at each sample date (ANOVA, $p>0.05$ ). Therefore, values were pooled per date as shown in Fig. 4. The $\delta^{13} \mathrm{C}$ trend was similar for the different tissues (muscle, digestive gland, mantle and total soft tissue) with a decrease over time. However, $\delta^{13} \mathrm{C}_{\text {muscle }}$ decreased from -14.7 to $-32.6 \%$ in 64 days whereas $\delta^{13} \mathrm{C}_{\text {digestive gland }}$ decreased from -17.5 to $-38.5 \%$ in 
275 only 7 days. Mantle $\delta^{13} \mathrm{C}$ values were not significantly different than the muscle $\delta^{13} \mathrm{C}$ value 276 (ANOVA, $p>0.05$ ) at $\mathrm{t}_{35}$. Total soft tissues $\delta^{13} \mathrm{C}$ values were between muscle and digestive 277 gland $\delta^{13} \mathrm{C}$ values.

\section{$3.4 \delta^{13} C_{s h e l l}$}

280 Shell carbonate sampled before the cleft in the shell, which represents three to four days of 281 growth in the field just before collection, had mean $\delta^{13} \mathrm{C}_{\text {shell }}$ values equal to $-0.83 \%$ o $(1 \sigma=$ $2820.26 \%$ ) as shown in Fig. 5. At day 7, shell material formed in experimental tanks showed a 283 decreased in $\delta^{13} \mathrm{C}_{\text {shell }}$ values in comparison to the field, with a mean value of $-6.48 \%$ o $(1 \sigma=$ $2840.80 \%$; i.e., a $5.65 \%$ decrease on average). After the salinity changes, mean $\delta^{13} \mathrm{C}_{\text {shell }}$ values 285 ranged from -5.03 to $-6.64 \%$ o for clams at salinity 35 , from -8.35 to $-9.82 \%$ o for clams at 286 salinity 28 and from -10.39 to $-12.11 \%$ o for clams at salinity 20 (Fig. 5). These shell $\delta^{13} \mathrm{C}$ 287 values were significantly different between the three salinities at $\mathrm{t}_{40}, \mathrm{t}_{52}$ and $\mathrm{t}_{62}$ (ANOVA, $p<$ 288 0.0001). There was a significant positive linear relationship between $\delta^{13} \mathrm{C}_{\text {shell }}$ and $\delta^{13} \mathrm{C}_{\mathrm{DIC}}\left(\mathrm{r}^{2}=\right.$ $2890.77, p<0.0001, \mathrm{n}=83$ ) as shown in Fig. 6.

\section{Discussion}

292 At the beginning of the experiment, clams were transferred from the field where the $\delta^{13} \mathrm{C}_{\mathrm{POM}}$

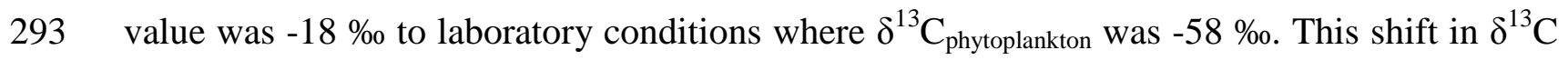
294 of the clams diet led to a decrease in $\delta^{13} \mathrm{C}$ in all tissues analyzed (muscle, digestive gland, 295 mantle and total soft tissues). This indicates a successful and quick incorporation of the 296 isotopically light dietary carbon from phytoplankton into clam tissues. In agreement with the 297 observation of Paulet et al. (2006) on Pecten maximus and Crassostrea gigas and Malet et al. 298 (2007) on Crassostrea gigas, our results indicate that the incorporation of dietary carbon is 299 faster in the digestive gland than in the muscle. This illustrates that the tissue turnover rate is 300 higher in the digestive gland than in the muscle.

301 In our study, there was no significant effect of salinity on the clams physiology as indicated 302 by the incorporation of carbon into the tissues, the condition index and shell growth rates. 303 These observations are in agreement with the results of Kim et al. (2001), who showed that 304 reasonable changes in salinity (35 to 20) have a small effect on activity rhythm and oxygen 305 consumption. Kim et al. (2001) report that Manila clams cannot maintain a normal metabolic 
activity at salinities lower than 15 and all clams died after an exposure at a salinity of 5 for 7 days.

Our results showed that the transfer from field to experimental conditions was followed by a decrease from -0.83 to $-6.48 \%$ in $\delta^{13} \mathrm{C}_{\text {shell }}$ in just 7 days (Fig. 5). Since the difference between field and laboratory $\delta^{13} \mathrm{C}_{\text {DIC }}$ was less than $1 \%$, the change in $\delta^{13} \mathrm{C}_{\text {shell }}$ was most likely due to the diet $\delta^{13} \mathrm{C}$ shift. This strongly suggests an incorporation of carbon derived from food into the shell. After 35 days, three salinity conditions were tested (20, 28 and 35). As expected, shifts in salinity resulted in shifts in $\delta^{13} \mathrm{C}_{\mathrm{DIC}}$ (as we mixed waters with different $\delta^{13} \mathrm{C}_{\text {DIC }}$ values), which was followed by significant changes of $\delta^{13} \mathrm{C}_{\text {shell }}$ values. These results experimentally confirmed an integration into the shell of both carbon from seawater DIC and metabolic DIC derived from food as suggested by number of authors (e.g. Tanaka et al., 1986, McConnaughey et al., 1997, Lorrain et al., 2004, Wanamaker et al., 2007, McConnaughey and Gillikin, 2008, Owen et al., 2008, Gillikin et al., 2006, 2007, 2009).

For both successive shifts $\left(\delta^{13} \mathrm{C}_{\text {phytoplankton }}\right.$ shift at $\mathrm{t}_{0}$ and $\delta^{13} \mathrm{C}_{\text {DIC }}$ shift at $\left.\mathrm{t}_{35}\right)$, the incorporation of carbon into the shell was very rapid: the first carbonate samples following both switches, which correspond to an average of nearly 7 days, had significantly different $\delta^{13} \mathrm{C}_{\text {shell }}$ than carbonate samples before the shifts. Because seawater DIC is presumed to be supplied in extrapallial fluids directly from the surrounding seawater through mantle epithelium and periostracum (see McConnaughey and Gillikin, 2008), a short incorporation time is expected. Interestingly the incorporation of carbon from food was also very rapid, which is not necessarily expected because assimilation and metabolic processes may occur at a longer time scale. This result suggests that during this experiment most respired $\mathrm{C}$ used in shell construction is derived from the direct oxidation of food and is not from stored $\mathrm{C}$ sources.

During this experiment, $\delta^{13} \mathrm{C}_{\text {DIC }}$ was not as constant as expected over time for the three salinities (Fig. 3A). As salinity was constant during this experiment (except the voluntary shift at $\left.\mathrm{t}_{35}\right), \delta^{13} \mathrm{C}_{\mathrm{DIC}}$ fluctuations are not explained by salinity variations. Two other hypotheses may be considered. (1) Clam respiration and calcification will modify the $\mathrm{CO}_{2}$ fluxes and then $\delta^{13} \mathrm{C}_{\mathrm{DIC}}$, however, aquaria water was continuously renewed at a rate of $25 \% \mathrm{~h}^{-1}$ (see Materials and methods), which would greatly reduce or even eliminate this effect on $\delta^{13} \mathrm{C}_{\mathrm{DIC}}$. Nevertheless, future studies should consider this and analyze $\mathrm{pH}$, total $\mathrm{DIC}, \mathrm{pCO}_{2}$ and even 
$339 \mathrm{O}_{2}$ levels as all these parameters have been proposed to influence shell $\delta^{13} \mathrm{C}$ (see 340 McConnaughey and Gillikin, 2008 for a review); (2) Variable quantities of food supplied to 341 the clams is a more probable cause of these $\delta^{13} \mathrm{C}_{\mathrm{DIC}}$ fluctuations. In order to obtain the 342 appropriate phytoplankton concentration within the clam tanks, the flow of algae culture 343 supplied was adjusted daily as a function of algae culture concentration and the number of 344 clams in the tank. The $\delta^{13} \mathrm{C}_{\text {DIC }}$ value in this algae culture was $-22 \%$ during this experiment. 345 Therefore, when variable quantities of algae solutions are supplied to the clams, 346 corresponding variable ${ }^{13} \mathrm{C}$-depleted DIC in the culture medium might induce differential $347 \delta^{13} \mathrm{C}_{\mathrm{DIC}}$ values within the clam tanks. Despite the relative instability of $\delta^{13} \mathrm{C}_{\mathrm{DIC}}, \delta^{13} \mathrm{C}_{\text {shell }}$ 348 followed the same variations as $\delta^{13} \mathrm{C}_{\text {DIC. The }}$. There was a positive linear relationship between $349 \delta^{13} \mathrm{C}_{\text {DIC }}$ and $\delta^{13} \mathrm{C}_{\text {shell }}$ during the experiment with a high correlation coefficient value $\left(\mathrm{r}^{2}=0.77\right.$, $350 p<0.0001, \mathrm{n}=83$, Fig. 6). It seems that, in this species, $\delta^{13} \mathrm{C}_{\text {shell }}$ may be a promising proxy of 351 large scale variations in $\delta^{13} \mathrm{C}_{\mathrm{DIC}}$ and therefore of salinity in estuarine water.

353 In order to estimate the percentage of metabolic carbon in the shell carbonate $\left(\mathrm{C}_{\mathrm{M}}\right)$, previous 354 studies used the classical two end-member mixing equation proposed by McConnaughey et al. 355 (1997): $\mathrm{C}_{\mathrm{M}}=100 \times\left(\delta^{13} \mathrm{C}_{\text {shell }}-\varepsilon_{\text {ar-b }}-\delta^{13} \mathrm{C}_{\text {DIC }}\right) /\left(\delta^{13} \mathrm{C}_{\mathrm{R}}-\delta^{13} \mathrm{C}_{\text {DIC }}\right)$ where $\varepsilon_{\text {ar-b }}$ is the enrichment 356 factor between bicarbonate and aragonite $\left(+2.7 \%\right.$; Romanek et al., 1992) and $\delta^{13} \mathrm{C}_{\mathrm{R}}$ is the 357 carbon isotope composition of respired carbon which has never been measured in bivalves. 358 According to Tanaka et al. (1986) and McConnaughey et al. (1997), $\delta^{13} \mathrm{C}_{\text {tissues }}$ values provide 359 a good approximation of $\delta^{13} \mathrm{C}_{\mathrm{R}}$. Nevertheless, there is no consensus on the tissue used to 360 estimate $\delta^{13} \mathrm{C}_{\mathrm{R}}$; consequently we performed this estimation with all potential $\delta^{13} \mathrm{C}_{\mathrm{R}}$ values 361 ( $\delta^{13} \mathrm{C}$ of muscle, digestive gland, mantle, total soft tissues and cultured phytoplankton). There was no significant difference between $C_{M}$ values calculated for the three salinity conditions with all potential $\delta^{13} C_{R}$ values and at any sampling date (Kruskal-Wallis, $p>0.05$ ). The 364 similarity between $\mathrm{C}_{\mathrm{M}}$ values at the three salinities seems to reject a strong impact of carbonic 365 anhydrase (CA) activity on shell $\delta^{13} \mathrm{C}$. Low salinity could result in decreased carbonic 366 anhydrase (CA) activity in the animal, as has been described for some bivalves (Henry and 367 Saintsing, 1983). In addition, CA activity has also been shown to be inhibited by $\mathrm{Cl}^{-}$ions 368 (Pocker and Tanaka, 1978) and therefore by salinity levels. Gillikin et al. (2006) hypothesized that $\mathrm{CA}$, which catalyses the reaction of bicarbonate to $\mathrm{CO}_{2}$, thereby facilitating diffusion of 370 DIC through membranes (Paneth and O'Leary, 1985), may add or remove carbon species 371 from the internal calcifying fluids. A reduction in CA activity due to low salinity could cause 372 a reduction in environmental DIC entering the animal, resulting in a larger relative 
373 contribution of metabolic DIC and more negative $\delta^{13} \mathrm{C}$ in the calcifying fluid and shell. Since 374 there was no significant difference between $C_{M}$ values calculated for the three salinity conditions, it appears that the salinity effect on CA activity and the ability of the animal to move environmental DIC into their calcification space is small or non-existent. The similarity between $\mathrm{C}_{\mathrm{M}}$ values at the three salinities also seems to reject a strong impact of possible varying $\mathrm{O}_{2}$ and $\mathrm{CO}_{2}$ levels on shell $\delta^{13} \mathrm{C}$ (see McConnaughey and Gillikin, 2008) that could arise with changing salinities. However, future studies should measure these parameters to estimate their role.

381 The estimated values of $\mathrm{C}_{\mathrm{M}}$ shown in Fig. 7 were highly sensitive to the type of tissue used for calculation and, at $\mathrm{t}_{7}, \mathrm{C}_{\mathrm{M}}$ values ranged from $21 \%$ using digestive gland to $50 \%$ using muscle (note that we calculated $\mathrm{C}_{\mathrm{M}}$ for each date based on $\delta^{13} \mathrm{C}_{\text {tissues }}$ values pooled from all salinities as there was no salinity effect on $C_{M}$ ). The estimations using $\delta^{13} C_{\text {mantle }}$ and $\delta^{13} C_{\text {total }}$ soft tissues resulted in intermediate values that ranged between the estimations made using muscle and digestive gland $\delta^{13} \mathrm{C}$ values. At the end of this experiment, these differences were reduced (12\% using digestive gland to $20 \%$ using muscle). Interestingly $\mathrm{C}_{M}$ values calculated with digestive gland or muscle, as a proxy for respired carbon $\delta^{13} \mathrm{C}$, between the clams collected at the end of the experiment and clams collected in the field, did not greatly differ (see Fig. 7, 17 vs $12 \%$ or 21 vs $20 \%$ using the digestive gland and muscle respectively). As clams in the laboratory were growing without sediments, this would suggest that ${ }^{13} \mathrm{C}$ depleted porewater plays little to no role in biomineralization (see McConnaughey and Gillikin, 2008). Indeed, incorporation of ${ }^{13} \mathrm{C}$ depleted porewater in the field would lead to more negative shell $\delta^{13} \mathrm{C}$ and then an overestimation of $\mathrm{C}_{\mathrm{M}}$ in the field. In our lab experiment, without such depleted porewaters, $C_{M}$ values should have been much smaller than the field if carbon from these waters was strongly incorporated into the shells. The $\mathrm{C}_{\mathrm{M}}$ fluctuations through time were higher using $\delta^{13} \mathrm{C}_{\text {muscle }}$ as $\delta^{13} \mathrm{C}_{\mathrm{R}}$ than using $\delta^{13} \mathrm{C}_{\text {digestive }}$ gland (50 to $20 \%$ using muscle; 21 to $12 \%$ using digestive gland). Interestingly, the estimation using $\delta^{13} \mathrm{C}_{\text {phytoplankton }}$ (which is lower than $\delta^{13} \mathrm{C}_{\text {tissues, }}$, especially at the beginning of the experiment) results in an even more constant estimation of $\mathrm{C}_{\mathrm{M}}$ over time than using $\delta^{13} \mathrm{C}_{\text {digestive }}$ gland, with a value close to $12 \%$. Since salinity variations didn’t affect the clams physiology and other experimental conditions such as temperature and food quantity were constant during this experiment, such a constant value can be expected. Moreover, a $C_{M}$ value of $12 \%$ is near 404 the typical value of $10 \%$ recorded for most aquatic mollusks (see McConnaughey and 405 Gillikin, 2008). Assuming that $\delta^{13} \mathrm{C}_{\mathrm{R}}$ is close to $\delta^{13} \mathrm{C}_{\text {phytoplankton during this experiment }}$ 406 illustrates that metabolic $\mathrm{CO}_{2}$ originates from very reactive tissues or directly from food 
oxidation when animals are fed continuously, and that muscle tissues were not appropriate to estimate $\mathrm{C}_{\mathrm{M}}$.

In the field, availability of energy (food) and energy allocation within bivalves is highly variable throughout the year (Paulet et al., 2006). During phytoplankton blooms, when metabolism is generally high, more of the carbon used for shell mineralization may be derived from metabolic $\mathrm{CO}_{2}$ which mainly results from oxidation of food. In such a case, $\delta^{13} \mathrm{C}_{\mathrm{R}}$ may be closer to $\delta^{13} \mathrm{C}$ values of phytoplankton. During less productive periods, carbon contribution may mainly come from DIC and because metabolism is mainly fuelled from reserves, $\delta^{13} C_{R}$ should be closer to $\delta^{13} \mathrm{C}$ values of storage organs (e.g. muscle). Thus, in bivalves, both proportion and carbon isotope value of metabolic carbon may be variable over the year. If this hypothesis is true, then studies investigating high frequency variations in $\delta^{13} \mathrm{C}_{\text {shell }}$ should use different tissues to estimate $\delta^{13} \mathrm{C}_{\mathrm{R}}$ according to the time period studied (digestive gland or phytoplankton during productive periods and muscle during less productive period). Studies that average more time (e.g. annual) can use tissues with a slower turnover rate, such as the muscle. However, under natural conditions the effect would be much smaller than in this study as in the field food items are not likely to vary as much as the $40 \%$ shift imposed in this study, and muscle and digestive gland $\delta^{13} \mathrm{C}$ values would not be so isotopically different (e.g. Lorrain et al., 2002).

Our study highlights that $\delta^{13} \mathrm{C}$ values of respired carbon are necessary to accurately determine the percentage of metabolic carbon integrated into bivalve shells. This respired $\mathrm{CO}_{2}$ is however very difficult to sample and has never been measured in bivalves.

\section{Conclusion}

This study experimentally highlights the incorporation of two carbon sources into shell carbonate: dissolved inorganic carbon from seawater and respired carbon derived from food. The incorporation time of both carbon sources into the shell is very short (less than 7 days). These short incorporation times indicate that proxies based on $\delta^{13} \mathrm{C}_{\text {shell }}$ may be used with high temporal resolution. Our experimental results also demonstrate that (1) the physiology of this euryhaline clam was not affected by the salinity treatments ranging between 20 and 35 during this experiment; (2) salinity does not seem to affect carbon cycling within the clam; and (3) $\delta^{13} \mathrm{C}_{\text {shell }}$ is highly correlated to $\delta^{13} \mathrm{C}_{\text {DIC }}$. Consequently, $\delta^{13} \mathrm{C}_{\text {shell }}$ of $R$. philippinarum is a 
440

441

442

443

444

445

446

447

448

449

450

451

452

453

454

455

456

457

458

459

460

461

462

463

464

465

466

467

468

469

470

471

472

473

474

475

476

477

478

479

promising proxy of large scale variations in $\delta^{13} \mathrm{C}_{\mathrm{DIC}}$ and therefore of salinity in estuarine water.

\section{Acknowledgements}

This work is a contribution to the PaleoSalt project funded by the European Science Fondation (ESF) under the EUROCORES Program EUROCLIMATE. The authors thank all the staff of the IFREMER shellfish laboratory at Argenton, particularly Pierrick Le Souchu, Christian Mingant, Luc Lebrun and Isabelle Queau; Jérémy Querné, Antoine Carlier and Jean-Marie Munaron for clam collection, technical assistance in clam dissection and water filtration; Mickael Korntheuer for technical support with the EA-IRMS and David Dettman for the carbonate isotopic analysis. This manuscript was greatly improved by comments from Jonathan Flye-Sainte-Marie and Julien Thébault and by reviews from Ted McConnaughey and Alan Wanamaker. We also thank the GDR IRD and IFREMER ACOMAR "Analyse, Compréhension et Modélisation des Archives biologiques marines" for funding. Support for this work was obtained also from the Science for Sustainable Development Program, Brussels via contract $\mathrm{SD} / \mathrm{CS} / 02 \mathrm{~A}$.

\section{References}

Andrus, C.F.T. and Rich, K.W., 2008. A preliminary assessment of oxygen isotope fractionation and growth increment periodicity in the estuarine clam Rangia cuneata. Geo-Mar. Lett 28 (5-6), 301-308.

Chauvaud, L., Lorrain, A., Dunbar, R.B., Paulet, Y.-M., Thouzeau, G., Jean, F., Guarini, J.M. and Mucciarone, D., 2005. Shell of the Great Scallop Pecten maximus as a highfrequency archive of paleoenvironmental changes. Geochem. Geophys. Geosyst. 6 (Q08001), doi:10.1029/2004GC000890.

Craig, H. and Gordon, L.I., 1965. Deuterium and oxygen 18 variations in the ocean and marine atmosphere. In: E. Tongiorgi (Editor), Stable Isotopes in Oceanographic Studies and Paleotemperatures Consiglio Nazionale delle Ricerche, Laboratorio di Geologia Nucleare, Pisa, pp. 9-130.

Davenport, C., 1938. Growth lines in fossil pectens indicators of past climates. J. Paleontol. $12(5), 514-515$.

Dettman, D.L., Flessa, K.W., Roopnarine, P.D., Schone, B.R. and Goodwin, D.H., 2004. The use of oxygen isotopic variation in shells of estuarine mollusks as a quantitative record of seasonal and annual Colorado River discharge. Geochim. Cosmochim. Acta 68 (6), 1253-1263.

Dillaman, R.M. and Ford, S.E., 1982. Measurement of calcium-carbonate deposition in mollusks by controlled etching of radioactively labeled shells. Mar. Biol. 66, 133-143. 
Dupont, C. and Marchand, G., 2008. Coastal exploitation on the neolithic of Western France: La pointe Saint-Gildas (Préfailles). Environmental archeology 13 (2), 143-152.

Dutton, A.L., Lohmann, K.C. and Zinsmeister, W.J., 2002. Stable isotope and minor element proxies for Eocene climate of Seymour Island, Antarctica. Paleoceanography 17 (2), doi: 1016, 10.1029/2000PA000593.

Epstein, S., Buchsbaum, R., Lowenstam, H.A. and Urey, H.C., 1953. Revised carbonate-water isotopic temperature scale. Geol. Soc. Am. Bull. 64, 1315-1326.

Epstein, S. and Mayeda, T., 1953. Variations of ${ }^{18} \mathrm{O}$ content of waters from natural sources. Geochim. Cosmochim. Acta 4, 213-224.

Flye-Sainte-Marie, J., Jean, F., Paillard, C., Ford, S., Powell, E., Hofmann, E. and Klinck, J., 2007. Ecophysiological dynamic model of individual growth of Ruditapes philippinarum. Aquaculture 266, 130-143.

Fry, B., 2002. Conservative mixing of stable isotopes across estuarine salinity gradients: a conceptual framework for monitoring watershed influences on downstream fisheries production. Estuaries Coasts 25 (2), 264-271.

Gillikin, D.P. and Bouillon, S., 2007. Determination of $\delta^{18} \mathrm{O}$ of water and $\delta^{13} \mathrm{C}$ of dissolved inorganic carbon using a simple modification of an elemental analyzer - isotope ratio mass spectrometer (EA-IRMS): an evaluation. Rapid Commun. Mass Spectrom. 21, 1475-1478.

Gillikin, D.P., Hutchinson, K.A. and Kumai, Y., 2009. Ontogenic increase of metabolic carbon in freshwater mussel shells. J. Geophys. Res. -Biogeosciences 114 (G01007), doi:10.1029/2008JG000829.

Gillikin, D.P., Lorrain, A., Bouillon, S., Willenz, P. and Dehairs, F., 2006. Stable carbon isotopic composition of Mytilus edulis shells: relation to metabolism, salinity, $\delta^{13} \mathrm{C}_{\text {DIC }}$ and phytoplankton. Org. Geochem. 37, 1371-1382.

Gillikin, D.P., Lorrain, A., Meng, L. and Dehairs, F., 2007. A large metabolic carbon contribution to the $\delta^{13} \mathrm{C}$ record in marine aragonitic bivalve shells. Geochim. Cosmochim. Acta 71, 2936-2946.

Goewert, A. and Surge, D., 2008. Seasonality and growth patterns using isotope sclerochronology in shells of the Pliocene scallop Chesapecten madisonius. Geo-Mar. Lett. 28, 327-338.

Goulletquer, P., Heral, M., Deslous-Paoli, J.M., Prou, J., Garnier, J., Razet, D. and Boromthanarat, W., 1989. Ecophysiology and energy balance of the Japanese clam Ruditapes philippinarum. J. Exp. Mar. Biol. Ecol. 132, 85-108.

Henry, R.P. and Saintsing, D.G., 1983. Carbonic-anhydrase activity and ion regulation in 3 species of osmoregulating bivalve mollusks. Physiol. Zool. 56 (2), 274-280.

Ivany, L.C., Lohmann, K.C., Hasiuk, F., Blake, D.B., Glass, A., Aronson, R.B. and Moody, R.M., 2008. Eocene climate record of a high southern latitude continental shelf: Seymour Island, Antarctica. Geol. Soc. Am. Bull. 120, 659-678.

Kim, W.S., Huh, H.T., Huh, S.H. and Lee, T.W., 2001. Effects of salinity on endogenous rhythm of the Manila clam, Ruditapes philippinarum (Bivalvia: Veneridae). Mar. Biol. 138 (1), 157-162.

Lazareth, C.E., Lasne, G. and Ortlieb, L., 2006. Growth anomalies in Protothaca thaca (Mollusca, Veneridae) shells as markers of ENSO conditions. Clim. Res. 30 (3), 263269.

Lorrain, A., Paulet, Y.-M., Chauvaud, L., Dunbar, R.B., Mucciarone, D. and Fontugne, M., 2004. $\delta^{13} \mathrm{C}$ variation in scallop shells: Increasing metabolic carbon contribution with body size? Geochim. Cosmochim. Acta 68 (17), 3509-3519. 
Lorrain, A., Paulet, Y.-M., Chauvaud, L., Savoye, N., Donval, A. and Saout, C., 2002. Differential $\delta^{13} \mathrm{C}$ and $\delta^{15} \mathrm{~N}$ signatures among scallop tissues: implications for ecology and physiology. J. Exp. Mar. Biol. Ecol. 275 (1), 47-61.

Lorrain, A., Savoye, N., Chauvaud, L., Paulet, Y.M. and Naulet, N., 2003. Decarbonation and preservation method for the analysis of organic $\mathrm{C}$ and $\mathrm{N}$ contents and stable isotope ratios of low-carbonated suspended particulate material. Anal. Chim. Acta 491 (2), 125-133.

Lucas, A. and Beninger, P.G., 1985. The use of physiological indices in marine bivalve aquaculture. Aquaculture 44, 187-200.

Malet, N., Sauriau, P.-G., Faury, N., Soletchnik, P. and Guillou, G., 2007. Effect of seasonal variation in trophic conditions and the gametogenic cycle on $\delta^{13} \mathrm{C}$ and $\delta^{15} \mathrm{~N}$ levels of diploid and triploid Pacific oysters Crassostrea gigas. Mar. Ecol.-Prog. Ser. 346, 203217.

Marin, M.G., Moschino, V., Deppieri, M. and Lucchetta, L., 2003. Variations in gross biochemical composition, energy value and condition index of T. philippinarum from the Lagoon of Venice. Aquaculture 219, 858-871.

McConnaughey, T.A., Burdett, J., Whelan, J.F. and Paull, C.K., 1997. Carbon isotopes in biological carbonates: respiration and photosynthesis. Geochim. Cosmochim. Acta 61 (3), 611-622.

McConnaughey, T.A. and Gillikin, D.P., 2008. Carbon isotopes in mollusk shell carbonates. Geo-Mar. Lett. 28, 287-299.

Miyajima, T., Yamada, Y., Hanba, Y.T., Yoshii, K., Koitabashi, T. and Wada, E., 1995. Determining the stable isotope ratio of total dissolved inorganic carbon in lake water by GC/C/IRMS. Limnol. Oceanogr. 40 (5), 994-1000.

Mook, W.G., 1971. Paleotemperature and chlorinities from stable carbon and oxygen isotopes in shell carbonate. Palaeogeogr. Palaeoclimatol. Palaeoecol. 9, 245-263.

Mook, W.G. and Tan, F.C., 1991. Stable carbon isotopes in rivers and estuaries. In: E.T. Degens, S. Kempe and J.E. Richey (Editors), Biogeochemistry of Major World Rivers. John Wiley and Sons Ltd, pp. 245-264.

Mook, W.G. and Vogel, J.C., 1968. Isotopic equilibrium between shells and their environment. Science 159 (3817), 874-875.

Nie, Z.Q., 1991. The culture of marine bivalve mollusks in China. In: W. Menzel (Editor), Estuarine and marine bivalve mollusk culture. CRC Press, Boston, pp. 261-276.

Owen, E.F., Wanamaker, A.D., Feindel, S.C., Schöne, B.R. and Rawson, P.D., 2008. Stable carbon and oxygen isotope fractionation in bivalve (Placopecten magellanicus) larval aragonite. Geochim. Cosmochim. Acta 72, 4687-4698.

Paneth, P. and O'Leary, M.H., 1985. Carbon isotope effect on dehydration of bicarbonate ion catalyzed by carbonic-anhydrase. Biochemistry 24, 5143-5147.

Paulet, Y.M., Lorrain, A., Richard, J. and Pouvreau, S., 2006. Experimental shift in diet $\delta^{13}$ C: A potential tool for ecophysiological studies in marine bivalves. Org. Geochem. 37 (10), 1359-1370.

Pocker, Y. and Tanaka, N., 1978. Inhibition of carbonic-anhydrase by anions in carbon dioxide-bicarbonte system. Science 199, 907-909.

Richardson, C.A., 1987. Tidal bands in the shell of the clam Tapes philippinarum. Proc. R. Soc. Lond. B 230, 367-387.

Romanek, C.S., Grossman, E.L. and Morse, J.W., 1992. Carbon isotopic fractionation in synthetic aragonite and calcite: effects of temperature and precipitation rate. Geochim. Cosmochim. Acta 56 (1), 419-430. 
Rowley, R.J. and Mackinnon, D.I., 1995. Use of the fluorescent marker calcein in biomineralisation studies of brachiopods and other marine organisms. Bulletin de l'Institut Oceanographique, Monaco 14, 111-120.

Schöne, B.R., Oschmann, W., Rössler, J., Castro, A.D.F., Houk, S.D., Kröncke, I., Dreyer, W., Janssen, R., Rumohr, H. and Dunca, E., 2003. North Atlantic Oscillation dynamics recorded in shells of a long-lived bivalve mollusk. Geology 31 (12), 10371040.

Surge, D., Lohmann, K.C. and Dettman, D.L., 2001. Controls on isotopic chemistry of the American oyster, Crassostrea virginica: implication for growth patterns. Palaeogeogr. Palaeoclimatol. Palaeoecol. 172, 283-296.

Tanaka, N., Monaghan, M.C. and Rye, D.M., 1986. Contribution of metabolic carbon to mollusk and barnacle shell carbonate. Nature 320, 520-523.

Thébault, J., Chauvaud, L., Clavier, J., Fichez, R. and Morize, E., 2005. Evidence of a 2-day periodicity of striae formation in the tropical scallop Comptopallium radula using calcein marking. Mar. Biol. 149 (2), 257-267.

Tripati, A., Zachos, J.C., Marincovich, L. and Bice, K., 2001. Late Paleocene Arctic coastal climate inferred from molluscan stable and radiogenic isotope ratios. Palaeogeogr. Palaeoclimatol. Palaeoecol. 70, 101-113.

Wanamaker, A.D., Kreutz, K.J., Borns, H.W., Introne, D.S., Feindel, S., Funder, S., Rawson, P.D. and Barber, B.J., 2007. Experimental determination of salinity, temperature, growth, and metabolic effects on shell isotope chemistry of Mytilus edulis collected from Maine and Greenland. Paleoceanography 22 (2).

Wanamaker, A.D., Kreutz, K.J., Schöne, B.R., Pettigrew, N., Borns, H.W., Introne, D.S., Belknap, D., Maasch, K.A. and Feindel, S., 2008. Coupled North Atlantic slope water forcing on Gulf of Maine temperature over the past millennium. Clim. Dyn. 31 (2), 183-194.

Weidman, C.R., Jones, G.A. and Lohmann, K.C., 1994. The long-lived mollusk Artica islandica - a new paleaoceanographic tool for the reconstruction of bottom temperature for the continental shelves of the northern North-Atlantic Ocean. J. Geophys. Res. 99 (C9 ), 18305-18314. 


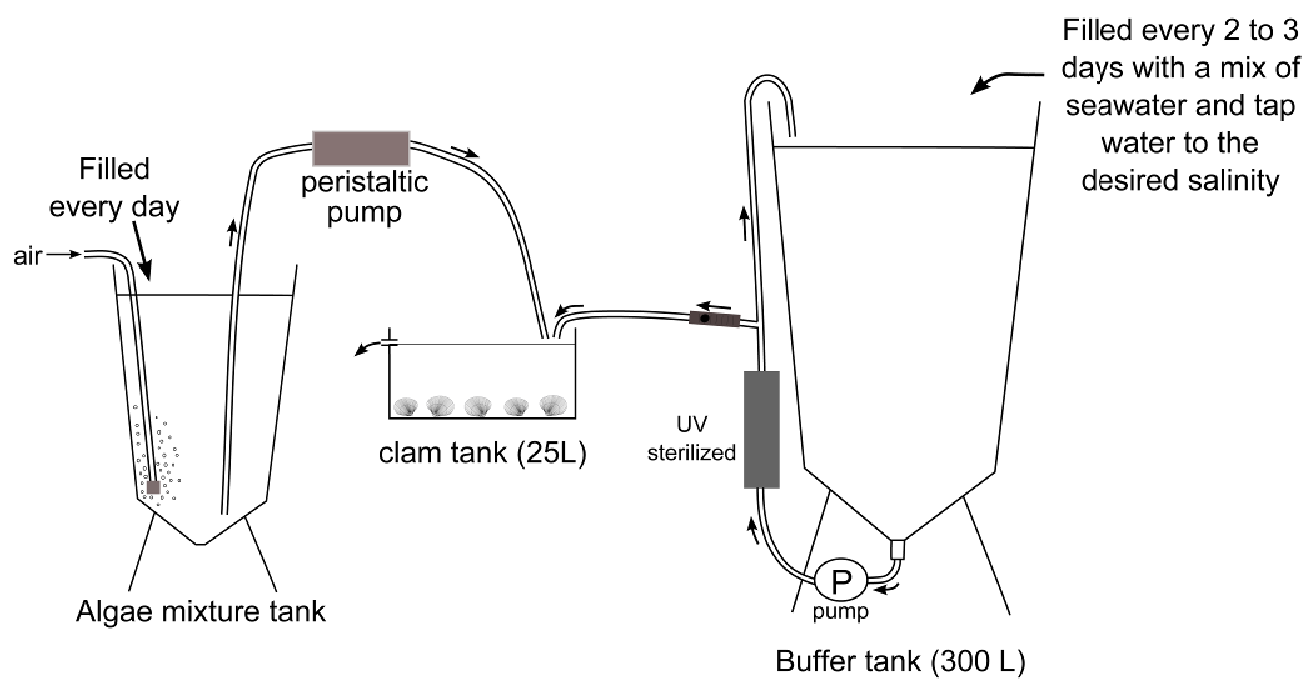

611

612 Fig. 1. Schematic diagram of the experimental system. The complete experimental system consisted of three clam and buffer tanks, one for each clam batch. The same algae culture was used for the three clam batches.
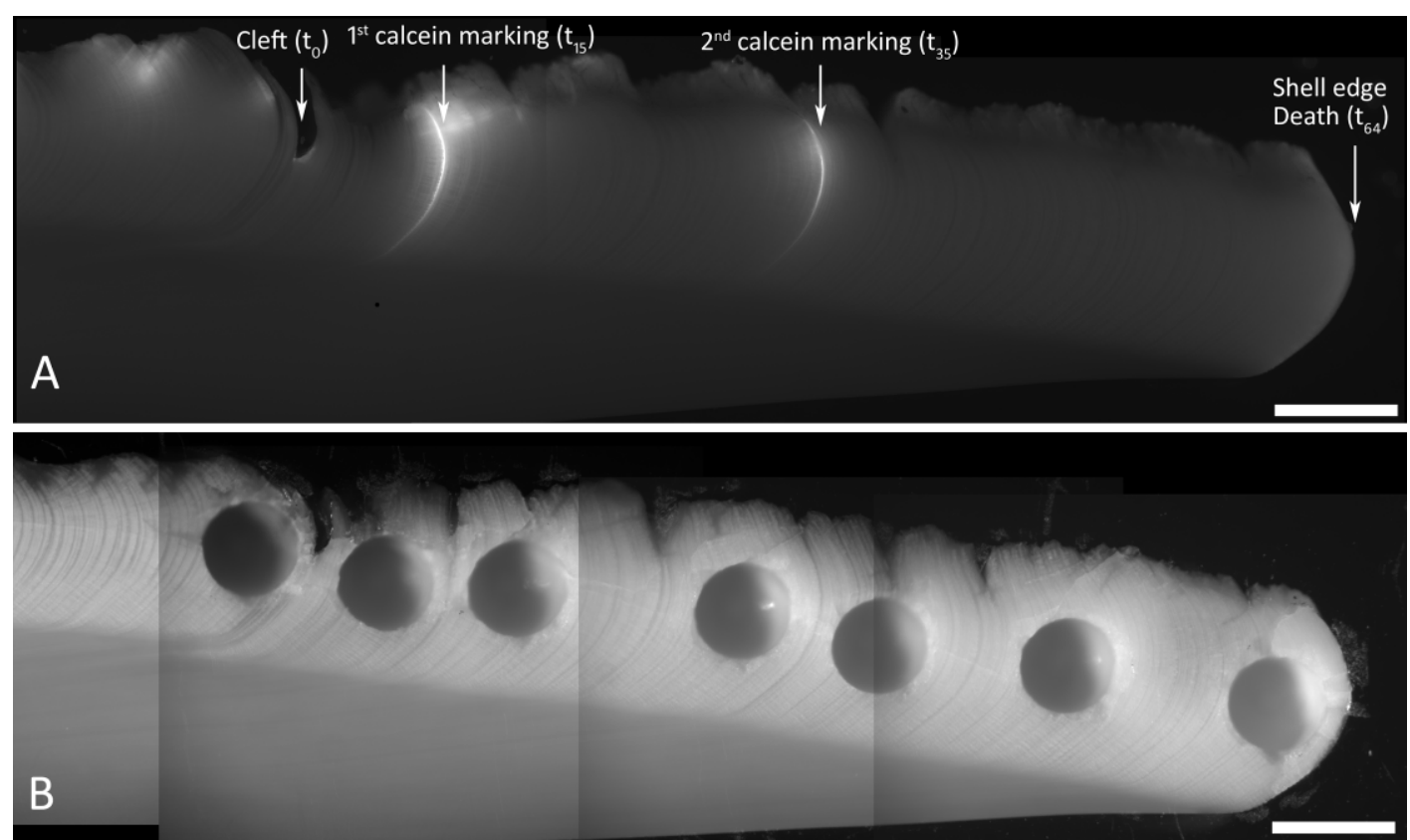

Fig. 2. Photographs of shell transversal section. Growth direction is left to right, the outside of the shell is toward the top of picture. A: The cleft corresponds to a growth stop due to clam harvesting in the field on the $18^{\text {th }}$ of August 2008. Clams were kept in laboratory for 64 days. The two calcein stains at $t_{15}$ and $t_{35}$ are visible. Shell edge corresponds to the end of the experiment. B: Drill holes (300 $\mu \mathrm{m}$ diameter; $350 \mu \mathrm{m}$ depth) made in the middle of the outer layer. Scale bar $=500 \mu \mathrm{m}$. 

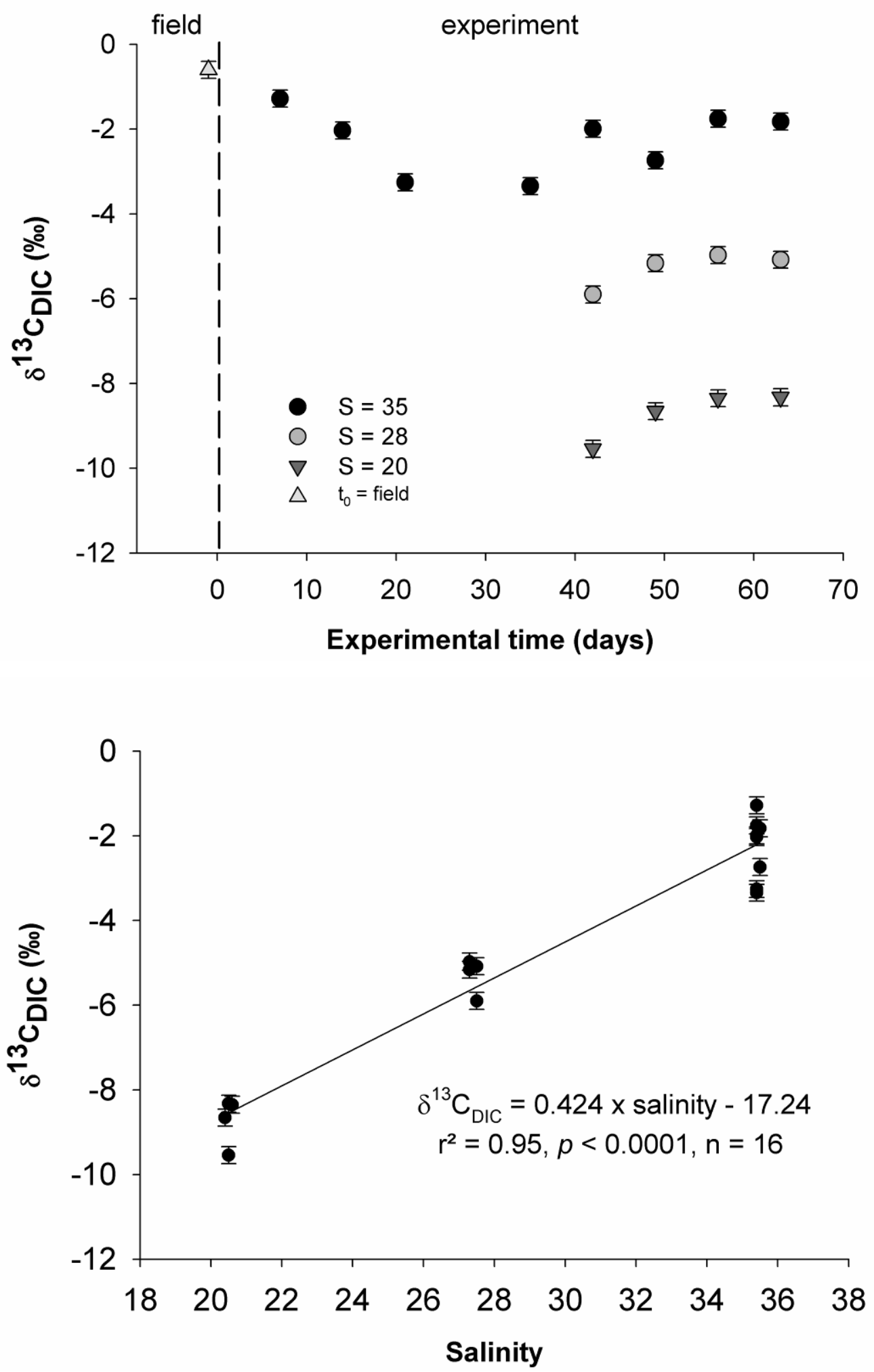

625

626 Fig. 3. A: DIC stable carbon isotope values $\left(\delta^{13} \mathrm{C}_{\text {DIC }}\right)$ during the experiment. Three salinity 627 conditions (20, 28 and 35$)$ were tested from days 35 to 64 . B: $\delta^{13} \mathrm{C}_{\text {DIC }}$ as a function of salinity 628 during the experiment. Error bars represent the analytical precision $(1 \sigma)$. 


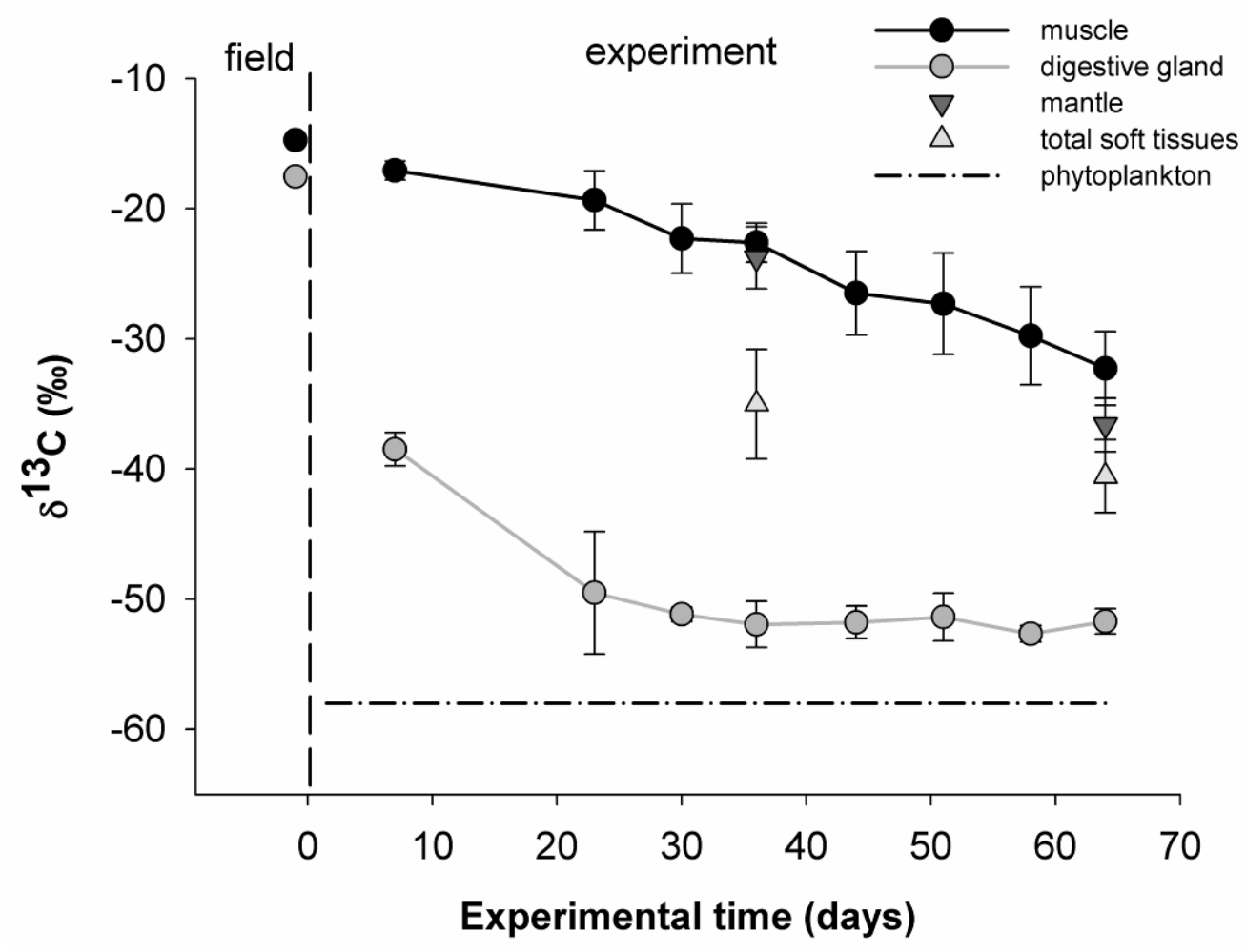

631 Fig. 4. Evolution of stable carbon isotope values $\left(\delta^{13} \mathrm{C}\right)$ of Manila clam tissues (muscle, 632 digestive gland, mantle and total soft tissues) and phytoplankton during the experiment.

633 Values are expressed as means and error bars represent standard deviations, $\mathrm{n}=5$ during the 634 first 35 days; $n=15$ from day 35 to 64 because the results for the three different salinities 635 were pooled.

636 


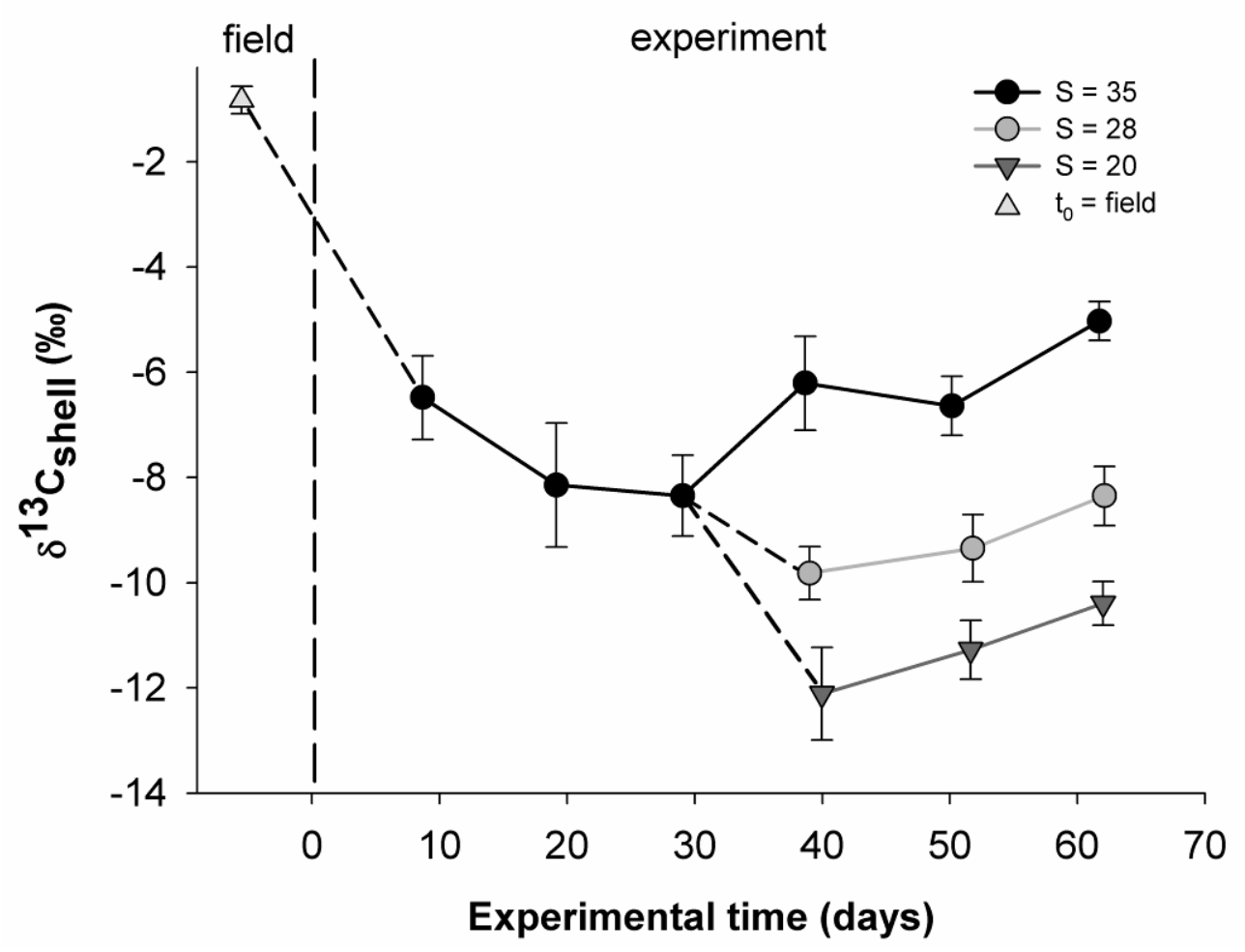

637

638 Fig. 5. Evolution of stable carbon isotope values $\left(\delta^{13} \mathrm{C}_{\text {shell }}\right)$ in $R$. philippinarum shells during 639 the experiment for the three salinity conditions (20, 28 and 35). Values are expressed as 640 means and error bars represent standard deviations, $n=15$ during the first 35 days; $n=5$ from 641 day 35 to 64 for each point.

642 


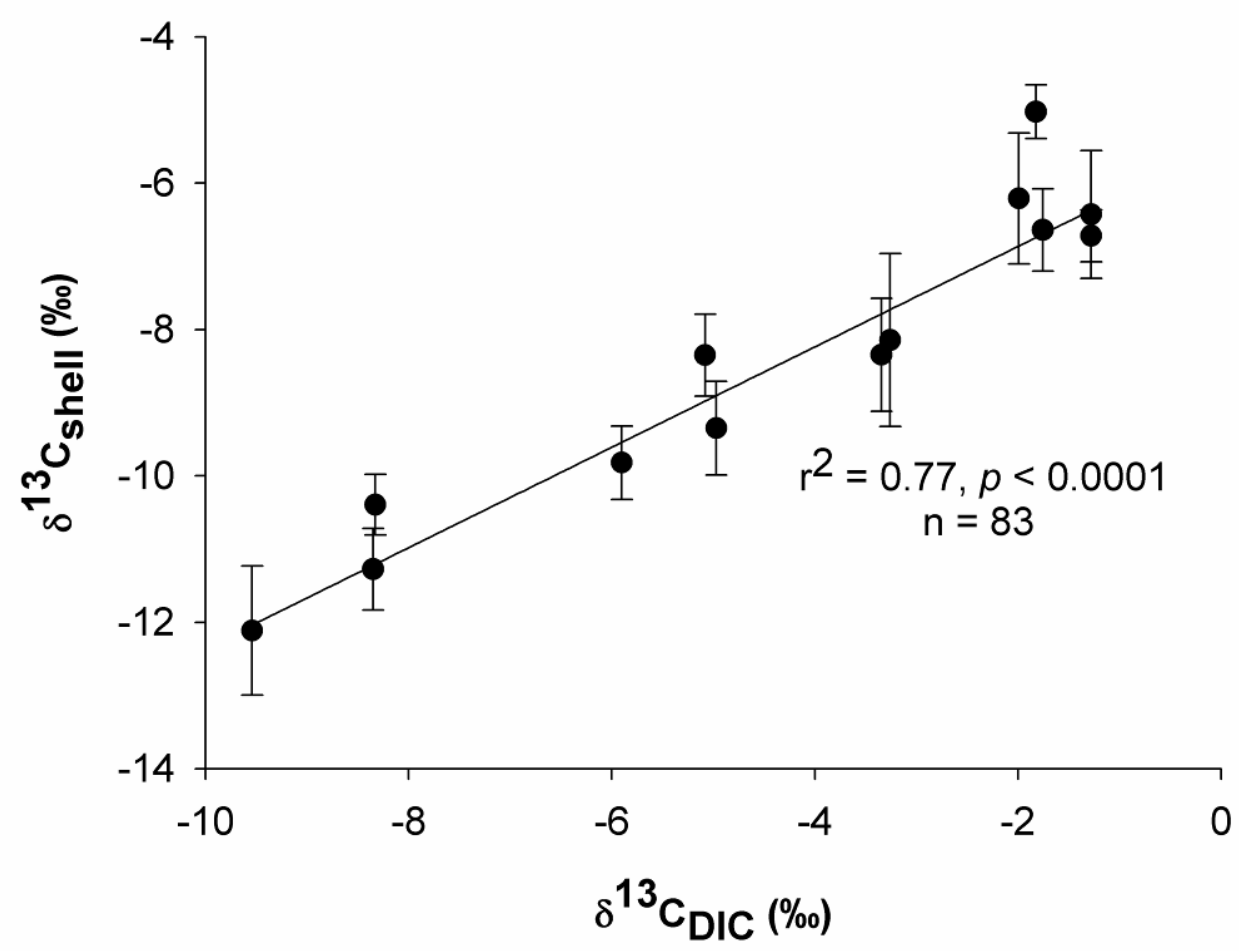

644

Fig. 6. $\delta^{13} \mathrm{C}_{\text {shell }}$ vs $\delta^{13} \mathrm{C}_{\mathrm{DIC}}$ in clam tanks for samples taken over the experiment. Error bars 646 represents standard deviations. The solid line shows the linear least squares regression 647 calculated with all data obtained during this experiment $\left(\mathrm{r}^{2}=0.77, p<0.0001, \mathrm{n}=83\right)$. 648 


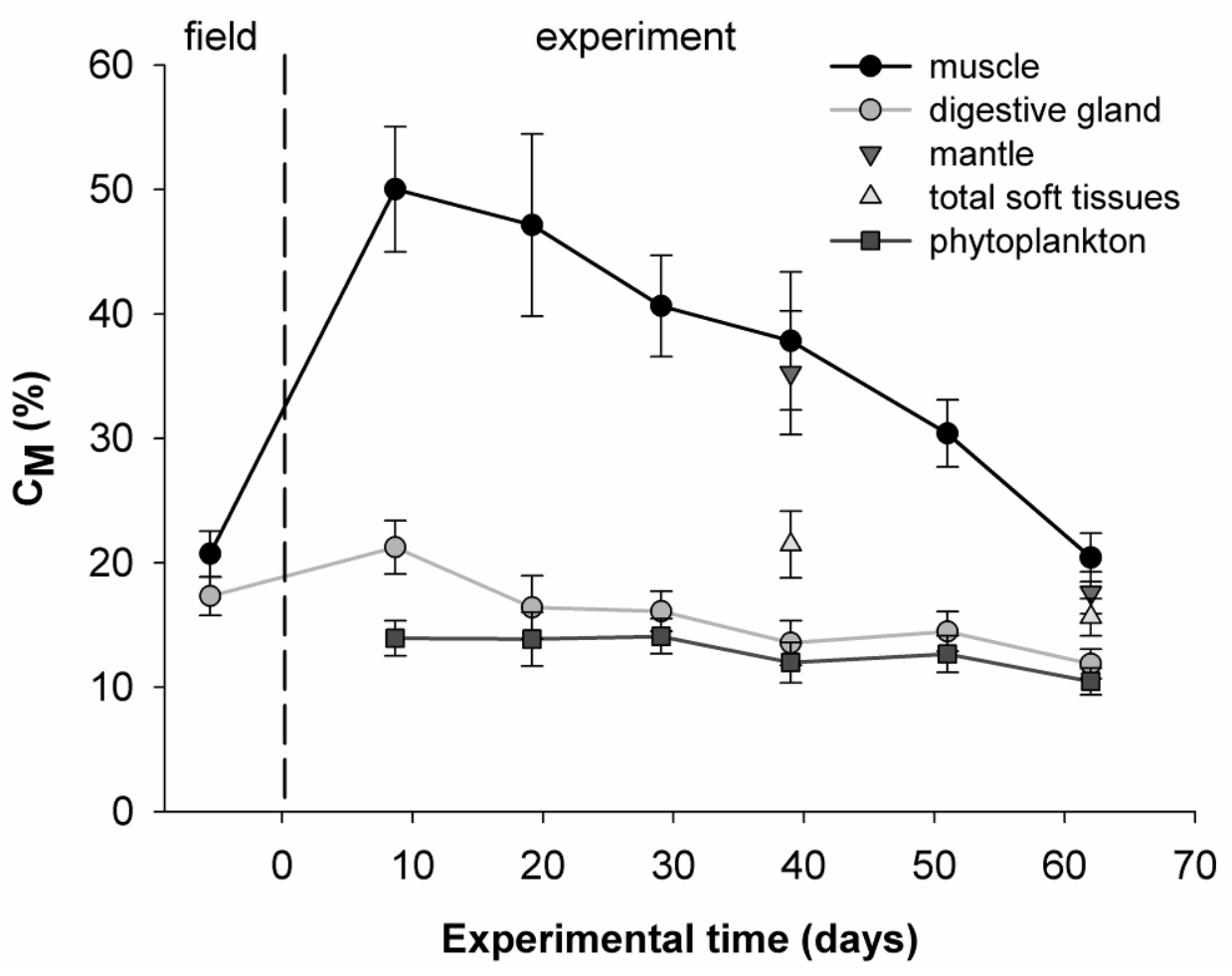

651 Fig. 7. Estimates of the proportions of metabolic carbon $\left(\mathrm{C}_{\mathrm{M}}\right)$ incorporated into shell 652 carbonates using the equation of McConnaughey et al. (1997). Muscle, digestive gland, 653 mantle, total soft tissues and phytoplankton carbon isotope composition were used to 654 approximate $\delta^{13} \mathrm{C}_{\mathrm{R}}$. Values are expressed as means and error bars represent standard 655 deviations. Different patterns are observed depending on the tissue used for the approximation 656 of $\delta^{13} \mathrm{C}_{\mathrm{R}}$. 